ZOOLOGIA 27 (4): 643-645, August, 2010

doi: $10.1590 /$ S1984-46702010000400011

\title{
A new Syllimnophora with a key to the species from Ecuador (Diptera: Muscidae)
}

\begin{abstract}
Márcia S. Couri
Museu Nacional, Universidade Federal do Rio de Janeiro. Quinta da Boa Vista, 20940-040 Rio de Janeiro, RJ, Brasil. E-mail: mcouri@terra.com.br

ABSTRACT. Syllimnophora Speiser belongs to the Limnophorini tribe of the Coenosiinae subfamily. The genus can be distinguished from the others by the presence of cilia on the apical half of the dorsal surface of vein $\mathrm{R}_{1}$, combined with a strongly projected gena. In he Neotropical Region 28 species are known, three of them recorded from Ecuador $-S$. atrovittata (Stein), S. browni (Snyder) and S. suavis (Stein). The study of material from South America deposited at Muséum national d'Histoire naturelle (Paris) enabled the description of one species new to science - S. argentifrontata sp. nov. from San Miguel de Ibarra (Ecuador). A key to the identification of the four species is given.
\end{abstract}

KEY WORDS. Morphology, Neotropical Region, new species, taxonomy, terminalia.

Adults of Syllimnophora Speiser, 1923 can be distinguished from the other Limnophorini (Coenosiinae) genera by the presence of cilia on the apical half of the dorsal surface of vein $\mathrm{R}_{1}$, combined with a strongly projected gena. In addition, the prosternum bears lateral cilia; the palpus is long, enlarged and flat at the apex; the ocellar triangle is long; the dorsocentral setae are 2+3; and the anepimeron is bare. The genus is known in the Neotropical Region from 28 species (CarvalHo et al. 2005) recorded from Argentina, Bolivia, Brazil, Chile, Colombia, Ecuador, Juan Fernández Island, Mexico and Peru. Three species have been recorded from Ecuador - S. atrovittata (Stein), $S$. browni (Snyder) and S. suavis (Stein).

Syllimnophora atrovittata was described by STEIN (1904) in Limnophora Robineau-Desvoidy, 1830 based on one female from Calanga, Peru. Later, the geographical distribution of the species was extended to Chile and Bolivia (STEIN 1911) and Colombia (Stein 1918). Pont (1972) transferred the species to Syllimnophora. LOPES \& BAPTISTA (1992), studying material from Ecuador, described and illustrated the male and female terminalia. STEIN (1911) presented a very short description of $S$. suavis (also in Limnophora), comparing it to L. compressifrons, as both species, according to him, are very similar morphologically, differing only in the color pattern of the scutum and abdomen and by the dark brown longitudinal cloud on the anterior margin of wing of $S$. suavis. The author also differentiated $S$. suavis from $S$. atrovittata, as both species have a similar cloud on the wing. SéguY (1937) transferred the species to Syllimnophora and Pont (1972) made notes on the type. The species was originally described from Peru and CAmpos (1960) recorded it from Ecuador. SNYDER (1957) described S. browni from one male and one female, both from Ecuador. The species was keyed and considered morphologically close to S. latimana Malloch, 1934, from which it can be distinguished by the golden yellow sternite 5 . The species is known only from the original material and remains endemic to Ecuador. Couri \& Carvalho (2002) presented the available keys to identification of the species.

This paper describes a new species and presents a key to the identification of the Syllimnophora recorded from Ecuador.

\section{MATERIAL AND METHODS}

The material belongs to the collection of the Muséum national d'Histoire naturelle, Paris (MNHN). The holotype of the new species and two paratypes are deposited at MNHN and one paratype is at the Museu Nacional, Rio de Janeiro (MNRJ).

For the dissection of the terminalia, the apex of the abdomen was macerated in a solution of $10 \%$ potassium hydroxide for 24 hours. After the dissection in glycerol, the structures were stored in a microtube attached to the pin bearing the specimen. The terminology of the descriptions followed McAlpine (1981).

\section{TAXONOMY}

The following key segregates the four species and is followed by the description of the new species. One female of $S$. atrovittata from Quito (R. Benoist leg., I/1930) was also identified in the examined material and is deposited at the MNHN.

Key to the species of Syllimnophora from Ecuador 1. Anterior margin of the wing with a dark brown mark reaching the end of vein $\mathrm{R}_{2+3}$ 2

1 '.Wings clear, with no dark marks ........................................ 3

2. Knob of the halteres yellow; hind tibia with one median anterodorsal seta (Colombia, Ecuador, Peru, Bolivia, Chile) S. atrovitatta (Stein) 


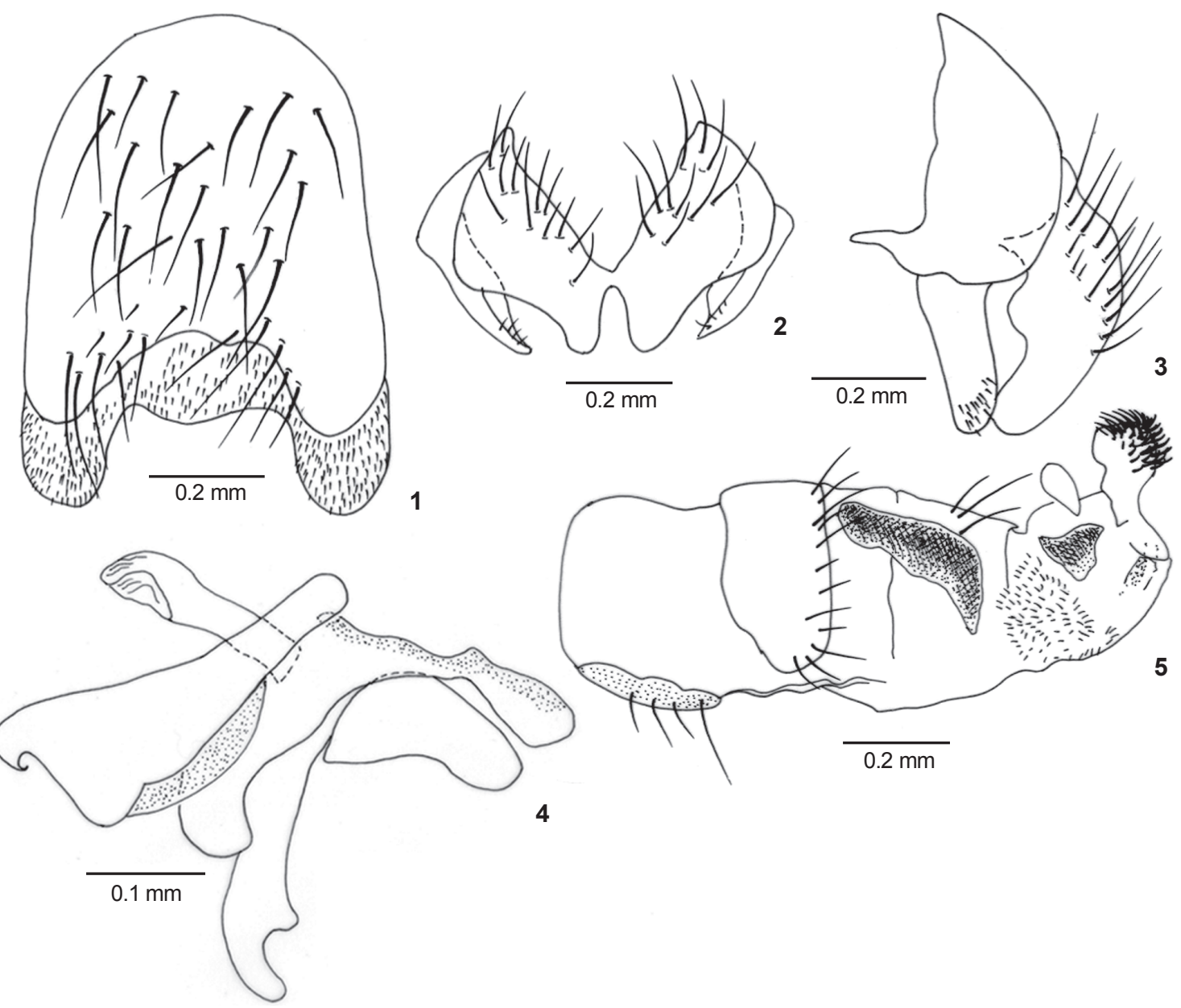

Figures 1-5. Syllimnophora argentifrontata sp. nov.: (1) sternite 5, dorsal view; (2) cercal plate and surstyli, dorsal view; (3) cercal plate and surstyli, lateral view; (4) phallic complex, lateral view; (5) ovipositor, lateral view.

2 '. Knob of the halteres brown; hind tibia with more than one median anterodorsal seta (Ecuador, Peru) S. suavis (Stein)

3. Body small, length about $4.5 \mathrm{~mm}$; knob of the halteres brown; mid tibia with three posterior setae; abdominal sternite 5 densely golden yellow (Ecuador) S. browni Snyder

3'. Body large, length about $7.0 \mathrm{~mm}$; knob of the halteres yellow; mid tibia with five posterior setae; abdominal sternite 5 brown with silver lateral areas and black marks (Ecuador) S. argentifrontata sp. nov.

\section{Syllimnophora argentifrontata sp. nov.}

Figs 1-5

Holotype: Male. Ecuador: Ibarra [San Miguel de Ibarra], R. Benoist leg., I.1930 (MNHN). Paratypes: two males (MNRJ and $\mathrm{MNHN}$ ) and one female (MNHN), same data as holotype.

Description. Male. Length: body 6.8-7.0 mm; wing 7.2 mm.
Color: face strongly silver pollinose, contrasting with the dark brown parafacial, fronto-orbital plate and gena. Antenna and arista dark brown. Palpus dark brown. Calypter uniformly whitish; halter yellow. Wing clear. Mesonotum brown, grey pollinose, with three large brown vittae, median vitta reaching apex of scutellum. Pleurae brown, grey pollinose. Legs dark brown. Abdomen brown with silver lateral round areas in all tergites and median longitudinal silver cloud on tergites $1+2-4$. Head: eyes finely and sparsely ciliated; distance between the eyes about 0.30 the width of the head. Inner and outer vertical setae long. Frontal row with five pairs of setae, intercalated with fine and short cilia; upper pair directed outwards. Ocellar setae long and directed forward; ocellar triangle with a tuft of short hairs. Postpedicel about 1.8 times the length of pedicel. Arista bare. Thorax: acrostichal hairs 0:1. Dorsocentrals 2+3. Presuturals 1; supra-alar 1; post supra-alar 1. Scutellum with two long pairs of setae, apical seta slightly little longer than basal. Anepisternun 
with six long setae. Fore femur with a complete row of setae on dorsal, anterodorsal and anteroventral surfaces. Tibia with a ventral and a dorsal apical seta, the latter longer. Mid femur with a complete row of setae on anterodorsal surface; ventral surface with a row of fine setae on basal half; posterior surface with two pre-apical setae. Mid tibia with five setae on posterior surface; anterior, ventral, posterodorsal and posteroventral surfaces each with apical seta. Hind femur with a complete row of setae on anterodorsal and anteroventral surfaces. Hind tibia with four anterodorsal setae on middle third, one anteroventral submedian, one dorsal preapical and one ventral apical. Abdomen: margin of tergite 4 and disc of tergite 5 with a series of fine setae. Sternite 5 higher than wider as in figure 1. Terminalia: Cercal plate and surstyli as in figures 2-3. Aedeagus as in figure 4 .

Female. Similar to male but series of anteroventral setae on hind femur restricted to 4-6 fine and spaced setae on basal half. Ovipositor as in figure 5.

Remarks. The silver frons contrasting with the dark brown head, combined with a clear wing, yellow halteres and hind tibia with four anterodorsal setae on middle third segregate this species from its congeners.

Etymology. The specific epithet refers to the strongly silver frons in both sexes.

\section{ACKNOWLEDGMENTS}

I am grateful to Christophe Daugeron and Emmanuel Delfosse (Muséum national d'Histoire naturelle, Paris) for the opportunity to study this material and for the daily help and to Andre M. Cunha (Museu Nacional, Rio de Janeiro) for the help in accessing the bibliography. To CNPq for the research post-doctoral grant (process number 201967/2008-1).

\section{LITERATURE CITED}

CAmpos, R.F. 1960. Las moscas (Brachycera) del Ecuador. Revista Ecuatoriana de Higiene y Medicina Tropical 17: 1-66.
Carvalho, C.J.B. De; M.S. Couri; A.C. Pont; D. Pamplona \& S.M. LOPEs. 2005. A Catalogue of the Muscidae (Diptera) of the Neotropical Region. Zootaxa 860: 1-282.

Couri, M.S. \& C.J.B. de Carvalho. 2002. Part II. Apical groups, p. 133-262. In: C.J.B. DE CARvalho (Ed.). Muscidae (Diptera) of the Neotropical Region: Taxonomy. Curitiba, Editora Universidade Federal do Paraná, 287p.

Lopes, S.M. \& P.P. BAPTISTA. 1992. Redescrição de algumas espécies de Syllimnophora Speiser, 1923 (Diptera, Muscidae, Coenosiinae, Limnophorini). Revista Brasileira de Zoologia 7: 495-501.

McAlpine, J.F. 1981. Morphology and terminology - adults, p. 9-63. In: J.F. McAlpine; B.V.Peterson; G.E.Shewell; H.J. Teskey; J.R. VOCKEROTH \& D.M. WOOD. Manual of Nearctic Diptera. Ontario, Research Branch Agriculture Canada, Monograph \#27, vol. 1, 674p.

Pont, A.C. 1972. Family Muscidae. In: A Catalogue of the Diptera of the Americas South of the United States. São Paulo, Museu de Zoologia, Universidade de São Paulo, 97, $111 \mathrm{p}$.

Séguy, E. 1937. Diptera Fam. Muscidae. In: P. Wytsman (Ed.). Genera Insectorum. Brussels, Desmet-Verteneuil, 205, 604p..

SNYDER, F.M. 1957. Notes and descriptions of some Neotropical Muscidae (Diptera). Bulletin of the American Museum of Natural History 113: 437-490.

Stein, P. 1904. Die amerikanischen Anthomyiden des Königlichen Museums für Naturkunde zu Berlin und des Ungarischen National-Museums zu Budapest. Annales Historico-Naturales Musei Nationalis Hungarici 2: 414495.

Stein, P. 1911. Die von Schnuse in Südamerika gefangenen Anthomyiden. Archiv für Naturgeschichte 77: 61-189.

Stein, P. 1918. Zur weitern Kenntnis aussereuropäischer Anthomyiden. Annales Historico-Naturales Musei Nationalis Hungarici 16: 147-244.

Submitted: 08.I.2010; Accepted: 30.V.2010.

Editorial responsibility: Gabriel L.F. Mejdalani 